\title{
ADDRESSING A FUTURE WITH DATA VISUALIZATION ON SCIENCE FICTION MOVIES: DYSTOPIA OR UTOPIA
}

\author{
Selçuk ARTUT \\ Sabanci University, Turkey \\ sartut@sabanciuniv.edu
}

\begin{abstract}
While the far-fetched ideas brought up with imagination are shedding lights on Science Fiction Movies, occasionally ever-growing technology has been fuelled by these creative inspirations and imaginations. This article reflects on the findings of the data visualization project Dystopia-Utopia (www.dystopia-utopia.com) and investigates the existence of a common discourse that would stand out in Science Fiction Movies as a significant social modifier. In this approach with the use of a built interactive Circular Hierarchial Edge Bundling Data Visualization system, the data provided by the online participants have been analyzed and the results show that Dystopia theme has been more frequently spoken in the discourse of mainstream Science Fiction Movies.
\end{abstract}

Keywords: Science Fiction, Data Visualization, Dystopia, Utopia, Edge Bundling

\section{BİLIM KURGU SINNEMASI BAĞLAMINDA VERI GÖRSELLEŞTİRME İLE GELECEĞİ YORUMLAMAK}

İnsanların hayal güçleri ile ortaya atılan fantastik fikirler bilim kurgu sinemasına farklı yönleriyle 1şık tutmaktayken kimi zaman sürekli gelişmekte olan teknoloji konu edilen bir çok hayal gücü öğesinden derinlemesine beslenmektedir. $\mathrm{Bu}$ araştırmada Distopya-Ütopya (www.dystopia-utopia.com) isimli internet sitesinde yayınlanan bir veri görselleştirme çalışmasının bulguları yansıtılmakta, Bilim Kurgu Sineması'nda toplumsal açıdan önem içeren ve öne çıkan bir söylemin olup olmadığı sorgulanmaktadır. Bu anlayışla Dairesel Hiyerarşik Kenar Demetleme Veri Görselleştirme yöntemi kullanılarak internet üzerinden katılımcıların görüşleri ile toplanan veriler analiz edilmekte ve sonuç olarak Distopya konusunun diğer konulara oranla daha fazla irdelendiği görüşü ortaya çıkmaktadır.

Anahtar Kelimeler: Bilim Kurgu, Veri Görselleştirme, Distopya, Ütopya, Kenar Demetleme

\section{Introduction}

With its inexorable penetration into our lives, technology does not only aim to serve for the sake of the humanity, but also it stands as a critical constituent to characterize the shape of the civilization of today and the future. The question of how technology pervades our lives drifts us into multilayered discussions with accompanying comprehensive analysis. In the light of the scientific explorations, humans have succeeded to go beyond the constraints of the nature with extensive use of technology in every confrontation of physical challenges. Furthermore, human imagination and creativity has exclusively brought new electrifying ideas into existence in the form of written expressions and thoughts in literature and arts (Nicolson 1956). In the light of this discussion, many masters of Sci-Fi writers such as Mary Shelley, Jules Verne, H.G. Wells, Hugo Gernsback, Aldous Huxley, George Orwell and many more names to be included in the discussion have challenged people's imagination with the use of Science Fiction's authentic discourse (Baxter 1970, Booker et al 2009, Brosnan 1978, Clute 1975).

It is observed that there are ongoing debates about where Science Fiction might have originated from, among the many arguments to list a few, some thoughts would argue that mythology has sci-fi imprints in its content (Goldschlager, 1997, Kilgour 2013). On the 
contrary alternative arguments would support that the idea commences with the Ancient Greek novels. Obviously, the ideas towards figuring out a common definition for the term Science Fiction are indeed multivariable due to its coextending nature of Science's unceasing progress. Even though in this article Science Fiction is not solely considered in the sphere of film studies, it's essential to identify the genre to a significant degree in order for the axis on which the conclusions are expressed to be fully comprehended. However, it's quite difficult to clarify the Science Fiction genre which had come about among different, entwined genres of the common features of its alikes and provide it with a unique, detached definition. One of the well-acknowledged definitions of Science Fiction comes from Darko Suvin (1972) who builds his explanation on the reception of estrangement based on an imaginative framework reflected in the creative discourse of a presented idea. Similarly, same feeling of estrangement would also be experienced in the show of the magicians. With the naked eyes, the participants are observing a series of actions performed by the magicians with enthusiasm. Instead of being totally excluded from the amusement, the participants are confronting with the skepticism of magic's persuasive power. Suvin goes on to complete his construction with the introduction of the term "novum". For Suvin novum (Latin for new thing) refers to the notions that are appreciated scientifically logical to a rational thinking. Therefore, the introduction of any technical instrument or an extraordinary situation could be secured under the umbrella of Science Fiction genre. From the audience point of view a novum challenges the norms of existing cultural and scientific conditions, but these challenging builds its own framing while remaining on the science's horizon. The concepts represented in the Science Fiction deliberately challenges the limits of the scientific discovery of the time of its author while using the thought experiments of pseudo-scientific methods (Robert 2002). According to Suvin, dawn of the Science Fiction manifests itself throughout the rise of the Sciences using a satirical style and it maneuvers into acquiring far more complex features in accordance with the natural and human sciences of the era. So, this parallelism does not necessarily require a close follow up of the scientific discoveries, instead the ideas created with the use of imaginative frameworks may also lead to inspirations for leading scientific studies. Consequently, Science Fiction's propositions may be acknowledged as plausible beings with the use of rational methods of science. Therefore, their existences do not contradict our cognitive reasoning. In the same fashion, Science Fiction is composed of works of intellect that combine one's imaginative and creative talents, produced on the axis of rational thought mindset brought by science. While presenting the intellectual content whose existence had not been scientifically accepted as of the respective moment, the Science Fiction thinker, overseeing the actual conditions of environment and time he/she's in, moves with the assumption that with the specific methods of science, it may become possible one day.

\section{Science's Spectacle Role and its stretch to Science Fiction Cinema}

Formerly many scientists, as seen more significantly through 17 th and 18th centuries, were performing Science, as a form of entertainment (Daniel 2007). As lots of experimental tools were intensively being utilized in scientific research during the Enlightenment Era that was mainly perceivable in Europe throughout 17 th century, they were simultaneously being used in various show-themed presentations. For example, in the 1800s, during times when Faraday was perfoming his experiments and presentations, the locations in which he was realising his performances were packed with crowds. The eclectic experiments that Faraday presented in front of spectators were astounding everybody. Apart from all the scientific outcomes, the scene was being perceived as impressive show of wizardry; in some form of an entertainment (Thomas 2013). As was highlighted by Bensaude-Vincent et al. (2008), science had started to share its distant academic position with an audience of popular "culture of curiosities". Arising scientific discoveries in fields like mechanics, electrics, chemistry and biology that had been becoming popular day after day, were being shared by an audience in public gatherings in every possible opportunity and science was gaining popularity among major crowds. Many tools and instruments produced in those scientific discoveries were being purchased by the aristocrats of the era as additions to their private collections. It can be stated 
that the scientists of the respective period had been living like superstars of our time because of the great interest shown to them by the surrounding society. As Fara (2009) mentions, many scientists, "natural philosophers" as they were called at the time, were quite wellendowed and wealthy. Scientist like Boyle, Priestley, Faraday, Lavosier, Volta, Nollet, Galvani, Gray and Franklin, owing to their discoveries, were not only keeping up with their scientific careers but, creating a public interest, were also presenting their uncommon discoveries to people, earning their admiration and able to achieve a substantial economic income. This condition allowed for two issues to become rigid. Primarily, scientists had started to prefer creating a line of work on the areas which had carried the opportunity to become popular, as the criterion of success. That's mainly why we can see many different experiments and shows gained popularity during 18th and 19th centuries, that used the power of electricity in particular with the invention of Leyden Jar. The second issue is, due to the instinct of acceptance as a consequence of reaching out to vast masses, that scientists had started to be pointed out as examplary models in public and scientific studies were rapidly being glamorised.

Because of all these reasons, science managed to attain the respect and the reputation art and music had been enjoying in the eye of the society. As a result of a social transformation process that placed science in its center, a birth of a modern civilization which had been determined to dominate the nature, became inevitable. Benjamin Franklin could bring the gigantic electricity from lightnings in the sky down to earth by means of a kite; by giving electricity to a dead frog, Galvani could make its legs move and with the Leyden jar, electricity could be consumed after being stored for a while and conducted from a human body. According to Bertucci (2007), the most common scientific public demonstration was electrifying Venus, or electric kiss, developed by George Matthias Bose. In this show, an alluring woman was charged with electricity on an electrically isolated stool and one of the guests was asked to kiss the woman on the lips. Trying to kiss the woman, the guest was meeting with electricity as a result of a powerful spark. While hundreds of this kind of experiments astonished people, a sense of admiration mixed with fun was rising for science in society. Science is considered by many to take a savior role, which was appeared in the light of rationalist view. But the rationalist view, therefore the scientific method, adopted the progression by evidences based on reality as a method. This situation enabled an era to surge, which Science Fiction rised, by pushing aside the fantasies and myths. Science fiction formed a different, distinctive structure using the language of science which was popular in the eye of the society. No doubt that many ideas, which were yet to be proven by science, were spoken in Science Fiction, the assumption that these ideas can be realized by scientific methods, were started to be used as a basic, creative thinking tool. Because of these reasons, Science aided to Science Fiction to gain popularity while showing up in literary texts. Today, Science preserves its popularity by being a cultural activity that feeds the sense of wonder in Science Fiction novels, cinematographic and theatrical productions, various science centers and many scientific periodical magazines. In this sense, Science Fiction Cinema can be described as a continuation of longstanding scientific entertainment traditions.

\section{Implementing the Data Visualization}

With a visually appealing framework that reflects conclusive analysis on a particular data set, data visualization methods enable the researchers to understand relatively complex phenomena in fine details. Additionally, with the popularity of implementing computational methods in various research areas, data visualization has been an effective method for investigating subjects with large number of dynamic data chunks. In the last few decades, because of increasing interest in utilizing visual forms to treat information as a data analysis source, there has been a proliferation of developing new comprehensive methods in establishing effective data visualization schemes. Having an easy access to many data visualization tools, the researchers are faced with a challenge to choose an appropriate method to transform the data into a meaningful configuration. Consequently, the nature of the data plays a substantial role in finding a relevant data visualization method. Even though the method to be implemented on a data could be as simple as a bar chart, it could also be 
extensively complicated as a network-mapping diagram. However, if a larger data set is to be considered, preferably the choice of data visualization alternatives may be narrowed down to chart diagrams, scatter plots, networks, heatmaps, treemaps etc. For the purposes of this study, in order to analyse the correlations between various Science Fiction Movies and particular themes, in-between node connections are required to be figured out. On the other hand, it is needless to say that since this research aims to investigate a subjective phenomenon to examine whether a particular theme has been emphasized more in Science Fiction Movies, criterias made to match films with a group of themes is obviously a subjective decision to be made. In order to overcome the monopoly of a single person's determination, a participatory web-based collective decision-making system has been developed for the participants to enroll in decision-making process. Users who contribute to the research can present their opinions in the online interactive form by matching a particular movie with a list of themes. For example, in Ex Machina (2015), written and directed by Alex Garland, it is observed that there is an opinion saying that the examined subjects are Altered State of Conciousness, Artificial Intelligence, Biological Engineering, Change in Human Condition, Criminal Organizations, Cyborgs, Extraterrestrial Invader, Human Cloning, Robot Invasion, Robotic War, Robots, Social Control and Utopia. The votes of users have been added to the database without any demographic classification. Any user's opinion is generated in an anonymous environment. As a result of the 1242 matchup suggestions submitted to the system as of the time of writing, the relationships between movies and themes can be visually examined by the data visualization study.

However, when large sets of node links are created between two sides, the visual outcome of such analysis is prone to have visual clutters. Within a limited space of visual layout, the problem of visual cluttering causes a congested representation of relationships among the nodes. Additionally, another representational problem occurs when a large number of items are to be listed on an axis; the list becomes so long to be displayed on a limited area. Decreasing font sizes of the items on the list remedies this problem to some extent, but then the names become extremely difficult to be read visually.

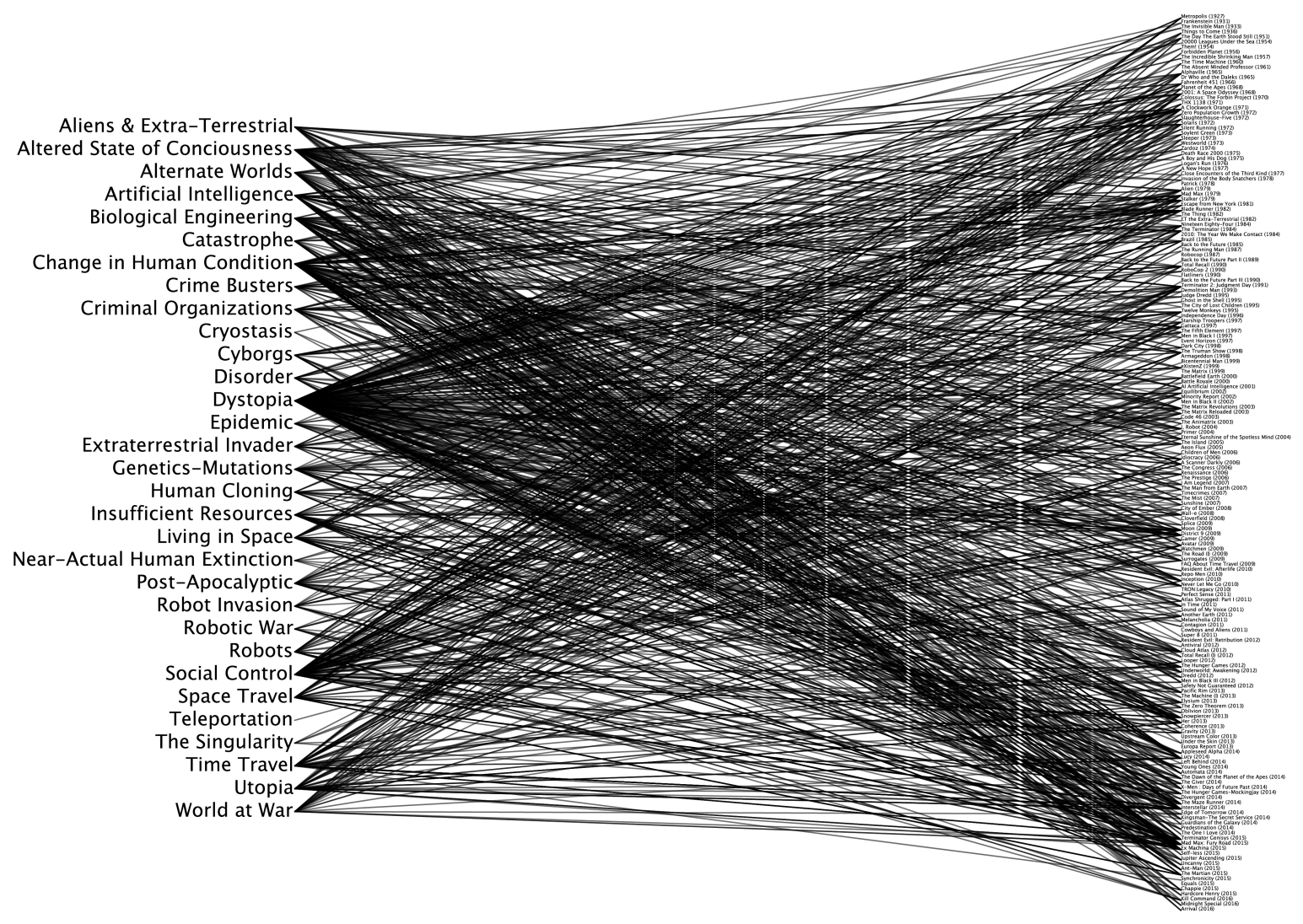

Figure 1. Visual Clutter Problem 
Alternatively, in order to overcome this complication, circular graph layouts would enjoy the advantage of distributing nodes on a perimeter of a circular structure. To avoid the visual cluttering; rather than using simple connecting lines, edge-bundling method enables us to use spline curves. As a result, visual representations of node relations are depicted in a deductible form that contains detailed edge-patterns. Hence data gathered from online participants have been analysed with a Circular Edge Bundling method (Zhou et al 2013) that permits a visual examination of a radial convergence towards a certain theme.

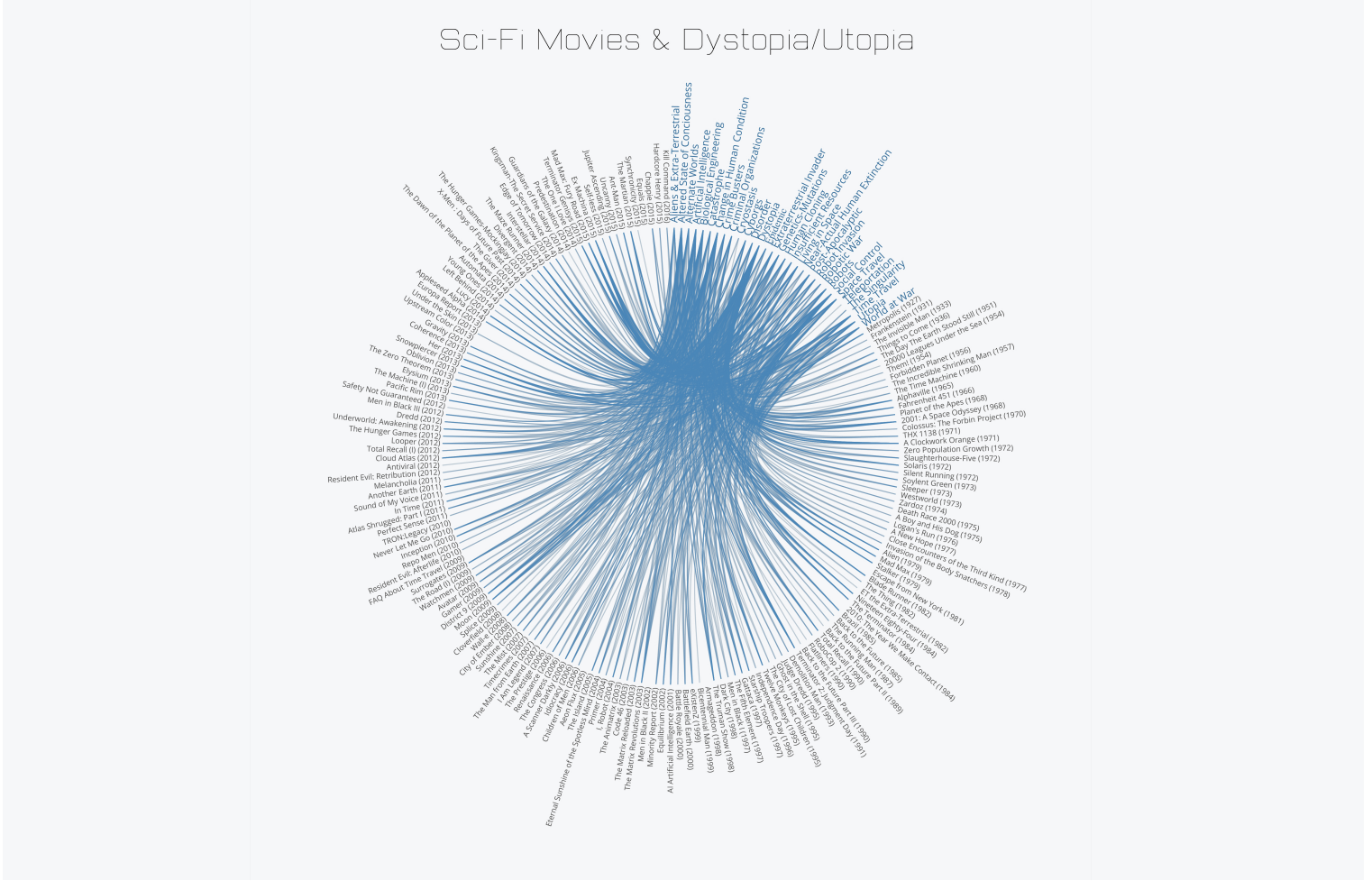

Figure 2. Edge Bundling Data Visualization

However, to represent the general picture for public opinion, the selected movies in this research were chosen as a criterion mainly for having received the highest average scores on the IMDB (Internet Movie Database) which is published on the imdb.com website. The resulting rating scores for the movies listed on the IMDB website are calculated from the mathematical averages of the scores which each individual user freely enters data into the online system. For this reason, the rating criterion posed by a common thought can lead to the selection of the movies included in the research. It is preferred that some selection criteria are applied in the research criteria because of the fact that there are many samples of Science Fiction cinema. A total of 177 popular Science Fiction movies have been examined for this research as of the time the article was written, and this figure continues to grow day by day with the suggestions from the participants.

The most important factor that feeds the survey in the sense of data is the ability to determine a quantitative view that will emerge with the votes of the participants. In this sense, it is aimed to free the participant as much as possible in the stage of giving opinions. That is why it is important to be able to be open to any suggestion of the theme that the researcher might get from the user, to avoid a possible mandatory direction. When the theme titles, proposed by online users, are examined and it is found that they have distinctive characteristics from other existing titles at a distinct level, they are also added to the theme list. 


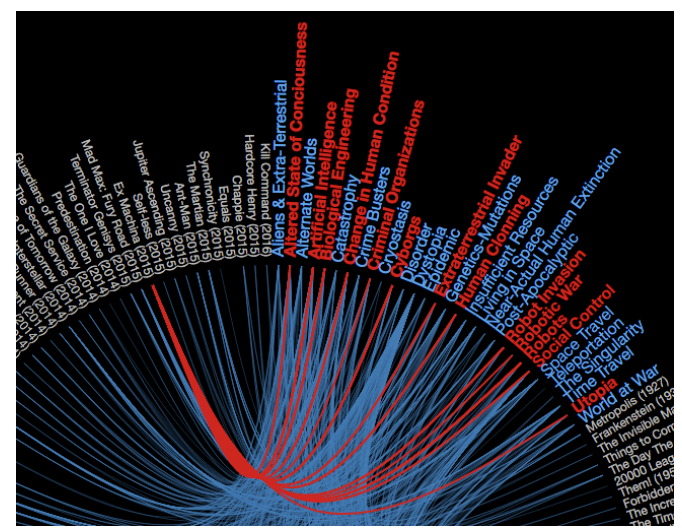

Figure 3. Themes in which Sci-Fi movie "Ex Machina" included

As a result, 177 movies that added to the scope of research, including the Metropolis, the oldest movie in the list (1927), are presented on the www.dystopia-utopia.com, the website where the research has been performed. Voluntary participants on the Internet match the listed movies with the themes listed in the online form application by their free will. Matching results are stored in the database, and links to interactive data visualization application are automatically generated by the system. An organized system was procured where the confidential correlations in the mixed and crowded data acquired at this point can be quickly recognized. Users can also examine the theme correlations on a single movie or movie correlations on a single theme in this system, which is interactive at the same time. Also, if double clicked on the name of the movie, any information about that movie can be accesses via the IMDB webpage.

\section{Results}

As a conclusion to the data visualization study, it can be said that the theme contents of the movies which are visually investigated by the Circular Edge Bundling method have a clear tendency towards the Dystopia topic. We can understand this situation at first glance from the intensity of the blue color correlations that are evident in the graphical representation applied based upon the correlations established between movies and themes. However, since it is understood that the data are close to each other regarding the correct ordering of the other themes, an extra study is needed. By using the statistical radar chart generated from the data provided, we can examine the mainly mentioned themes in the following figure.

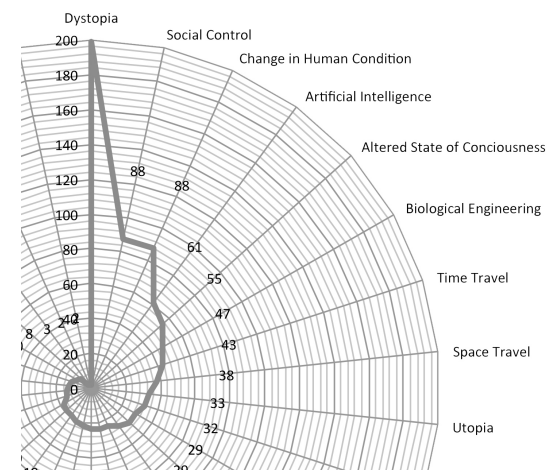

Figure 4. Radar chart of voted themes

It is also confirmed by the radar graph that the most mentioned theme is Dystopia. In addition, we can see that Social Control, A Change in Human Condition and Artificial Intelligence are intensively viewed respectively. We also understand in a more detailed observation that Mad Max: Fury Road (2015) is the highest rated movie regarding Dystopia theme. The most mentioned movie is Ex Machina (2015), which there is no opinion that considers it in the Dystopia theme. And it is followed by Interstellar (2014) and Mad Max: Fury Road (2015) 
Science Fiction Cinema is a genre of cinema that has become very popular and followed by wide audience in the past decades. This genre, which has many followers from various parts of society at all ages, is not only an entertainment made up of visual effects but also the content of the subject is getting ever richer and can make new discourses to be opened in people's philosophical minds. From this point of view, Science Fiction Cinema emerges as an important criterion in questioning the pros and cons of science. The general opinion supported by the participants, as seen in this survey, is that Science Fiction cinema more often discusses the Dystopia concept. Certainly, it is inevitable that the anxiety and fear instincts are crucial elements, as depicted in popular cinema examples. Although the movies listed under the title dystopia are exposed to many paintings filled with adversities, the main factor that makes movies engrossing is the thought that there are search for solutions and hopes to get rid of these negativities. For this reason, it is possible to talk about the contents of a transition from dystopia to utopia, since most popular movies have pleasing endings.

When the movies included in this research are viewed by years, it is observed that the movies that are recently produced were voted more frequently than the others. It can be infered that the users who participated in the research have less access to the former movies compared to the recent movies. Of course, it is harder for viewers to reach to earlier movie, which can be watched easily in different media formats. Another topic of debate is the subjective interpretation of the concepts of dystopia and utopia. Some opinions interpret the concept of dystopia differently, and to some, they can be perceived as a future utopian which can be considered as dystopian. Therefore, although two concepts are distinct from each other by definition, interpretation as to which cases are utopia or dystopia is subjective.

\section{References}

Baxter, J. (1970). Science fiction in the cinema (No. 1). AS Barnes.

Bensaude-Vincent, B., \& Blondel, C. (Eds.). (2008). Science and spectacle in the European Enlightenment. Ashgate Publishing, Ltd..

Bertucci, P. (2007). Sparks in the dark: the attraction of electricity in the eighteenth century. Endeavour, 31(3), 88-93.

Bertucci, P. "Domestic Spectacles: Electrical Instruments between Business and

Conversation." Science and Spectacle in the European Enlightenment. Ashgate, 2008. Print. (Electic Kiss)

Booker, M. K., \& Thomas, A. M. (2009). The science fiction handbook. John Wiley \& Sons. Brosnan, J. (1978). Future tense: the cinema of science fiction. Macdonald and Jane's.

Clute, J. (1995). Science fiction: The illustrated encyclopedia. Dk Pub.

Daniel, R. (2007). Science on the fairgrounds: from black to white magic. Science \& Education, 16(6), 585-591.

Fara, P. (2009). An Entertainment for Angels: Electricity in the Enlightenment. Icon books. Gansner, E. R., \& Koren, Y. (2006, September). Improved circular layouts. In International Symposium on Graph Drawing (pp. 386-398). Springer Berlin Heidelberg.

Goldschlager, A., \& Eos, A. (1997). Science Fiction \& Fantasy: A Genre With Many

Faces. SF Site: the Home Page for Science Fiction and Fantasy.

Holten, D. (2006). Hierarchical edge bundles: Visualization of adjacency relations in hierarchical data. IEEE Transactions on visualization and computer graphics, 12(5), 741748.

Holten, D., \& Van Wijk, J. J. (2009, June). Force-Directed Edge Bundling for Graph

Visualization. In Computer graphics forum (Vol. 28, No. 3, pp. 983-990). Blackwell

Publishing Ltd.

Kilgour, M. (2013). The rise of the Gothic novel. Routledge.

Nicolson, M. H. (1956). Science and imagination (No. 654). Great Seal Books.

Suvin, D. (1988). Positions and presuppositions in science fiction. Springer.

Suvin, D. (1972). On the poetics of the science fiction genre. College English, 34(3), 372-382. Suvin, D. (1979). Metamorphoses of science fiction: On the poetics and history of a literary genre. Yale University Press. 
The Turkish Online Journal of Design, Art and Communication - TOJDAC October 2017 Volume 7 Issue 4

Thomas, P. L. (Ed.). (2013). Science fiction and speculative fiction: Challenging genres. Springer Science \& Business Media.

Zhou, H., Xu, P., Yuan, X., \& Qu, H. (2013). Edge bundling in information visualization. Tsinghua Science and Technology, 18(2), 145-156. 